\title{
Validating and Examination Employees on Daily Basis using Simple Database Management System
}

\author{
Anudevi, V.Sailaja, S.Binapani
}

\begin{abstract}
Training is one of the human resource management department's main functions. Education refers to a formal set-up where workers are trained and taught work-related technical knowledge issues. This focuses on teaching staff how to use different equipment or how to execute certain tasks in order to increase efficiency. This article is mainly based on secondary data and it reveals the concept of human resource training.
\end{abstract}

Keywords : Induction, Vestibule training, Apprenticeship, turnover.

\section{INTRODUCTION}

Education is a fundamental concept in the development of human capital. It is concerned with the production by guidance and training of a particular skill to a desired level[1]-[5]. Education is a very useful tool that can place an employee in a role where they can do their job properly, effectively and conscientiously. Training is the act of increasing an employee's knowledge and ability to do a specific job.

Learning is the process of growing an employee's skills to do a particular job, according to Edwin Flippo. It's Dale. S. Beach defines training as the organized procedure by which, for a definite purpose, people learn knowledge or skills[6]-[8].

\section{REVIEW OF LITERATURE}

In his research, Maimuna Muhammad (2013) presents a literature review of employee performance training and development. His article revealed optimal returns from their investment for the organization. Education and growth are instruments that allow human capital to exploit its dexterity. Learning and growth is therefore important to the workers of the company[9]-[11].

In his study, Waqar Younas (2018) investigated the impact on employee performance of training and development. Findings showed that growth for sustainable long-term competitive edge leads to better employee performance,

Revised Manuscript Received on July 22, 2019.

Anudevi, Department of Science and Humanities, Bharath Institute of Higher Education and Research, Chennai , India. Email: Anudevi28@gmail.com

V.Sailaja, Department of Science and Humanities, Bharath Institute of Higher Education and Research, Chennai , India. Email: psaillajagmail.com

S.Binapani, Department of Science and Humanities, Bharath Institute of Higher Education and Research, Chennai , India. Email: bina.saravanangmail.com learning and employee development.

\section{RESEARCH METHODOLOGY}

This study was carried out using secondary data from books, journals, magazines and so on.

Requirement for preparing emerges in view of following reasons:

\section{A. Environmental Changes}

Motorization, computerization and mechanization have resulted in numerous progressions requiring enough skills from trained personnel[12]-[15].

\section{B. Organizationall Complexity}

With the advances of the present day, the mechanical improvement and enhancement of the majority of the community has become mysterious. To order to adapt to the dynamics, planning has become imperative along these lines.

\section{Human Relations}

Each the board needs to keep up great human connection and this has made preparing as one of the fundamental conditions to manage human issues[16]-[18].

\section{RESULT AND DISCUSSION}

\section{A. Importance Of Training}

In this progressively changing condition preparing of workers and chiefs are exceptionally fundamental. It improves the competency of workers. Preparing offers staff a lot of benefits, such as improving skills and adequacy, promoting fearlessness, and so on[19]-[21].

Accomplishment of association relies upon the preparation granted to the workers. Preparing additionally improves the quality and lessen the wastages to the base.

\section{B. Types Of Training}

A portion of the usually utilized preparing projects are recorded beneath:

\section{Induction Training}

So as to cause the newcomers to acquaint with the inner condition of an association, enlistment preparing is given.

\section{Job Instruction Training}

The training offers a description of the job and the 
whole profession is shown by experienced coaches.

\section{Vestibule Training}

It is the training for real work, however, to be finished away from the workplace by an employee.

\section{Refresher Training}

This training is provided to incorporate in a specific field the most recent development. This training is offered to reform representatives ' skills[22]-[24].

\section{Apprenticeship Training}

Laborer who invests an endorsed time of energy under a manager.

\section{Training Features}

1. Education is an instrument of inspiration.

2. Education is primarily related to employment and has to be focused in order to improve employee performance.

3 . It allows representatives to manage changing jobs and parts.

4. Develop the most efficient knowledge, skills and attitude to handle jobs.

\section{Pros And Cons Of Trining Employees PROS For EMPLOYE TRAINING}

1. It may reduce the turnover of employees.

2. Better training will reduce staffing costs in the long term.

3. Everyone gets to the same site.

4. Thera is the prospect of building a team.

5. Clearing expectations is an easy way[25].

\section{CONS OF EMPLOYE TRAINING}

1. Employees can take a competitor with their skills.

2. The training costs never go away.

3. Improper training results in inappropriate results.

4. In different ways, different people learn best.

5. It can cause resentment.

\section{CONCLUSION AND SUGGESTIONS}

- Education is an essential requirement for employee growth. EOLBREAK-Organization provides their staff with education once they are aware of the need for training.

- Also, training should be provided accurately otherwise it leads to wastage of resources.

\section{SUGGESTIONS}

- Communicate better and avoid mass training.

- Avoid mass feedback too.

- Consider exactly how people learn.

- Keep enabling learning and development.

\section{REFERENCES}

1. Vasanthi, S. \& Rabiyathul Basariya, S. 2019, "Influence of value analysis and cross training in industry", International Journal of Engineering and Advanced Technology, vol. 8, no. 6, pp. 1810-1811.

2. Velvizhi, R., Sri Gowtham, S. \& Jeya Priya, D. 2019, "Examination of early feedbacks for effective product retailing on E-commerce websites", International Journal of Engineering and Advanced Technology, vol. 8, no. 6 Special Issue 2, pp. 703-706.

3. Anuradha, C., Pothumani, S. \& Kavitha, R. 2019, "A novel method towards E-commerce", International Journal of Engineering and Advanced Technology, vol. 8, no. 6 Special Issue 2, pp. 535-538.
4. Thomas, J. \& Rabiyathul Basariya, S. 2019, "A study on the issues of financial ratio analysis", Indian Journal of Public Health Research and Development, vol. 10, no. 3, pp. 1079-1081.

5. Ramachandran, S. \& Rabiyathul Basariya, S. 2019, "Online marketing study on customer satisfaction and relationship", Indian Journal of Public Health Research and Development, vol. 10, no. 3, pp. 1072-1078.

6. Priya, R., Vinothini, G. \& Cor Jesu, C.D. 2019, "The mentor-protégé relationship for professional growth", Journal of Advanced Research in Dynamical and Control Systems, vol. 11, no. 9 Special Issue, pp. 1110-1119.

7. Jannifer Rani, N., Bina Pani, S. \& Nimisha, N.S. 2019, "A study on money back polices available in LIC", Journal of Advanced Research in Dynamical and Control Systems, vol. 11, no. 9 Special Issue, pp. 833-839.

8. Saillaja, V., Jhansi Rani, K. \& Catherine, R. 2019, "Global marketing management planning and organization", Journal of Advanced Research in Dynamical and Control Systems, vol. 11, no. 9 Special Issue, pp. 489-493.

9. Saillaja, V., Jhansi Rani, K. \& Catherine, R. 2019, "The new phase of marketing information system", Journal of Advanced Research in Dynamical and Control Systems, vol. 11, no. 9 Special Issue, pp. $482-488$

10. Thoufiqulla \& Raju, D.V. 2019, "Perception of indian investor towards investment in mutual funds with special reference to mip funds", Journal of Advanced Research in Dynamical and Control Systems, vol. 11, no. 5, pp. 177-183.

11. Jasmine, K.R.M. \& Basariya, S.R. 2018, "A study on the customers benefits on mutual funds", International Journal of Civil Engineering and Technology, vol. 9, no. 4, pp. 45-48.

12. Vasanthi, S. \& Basariya, S.R. 2019, "Pros and cons of on the job training versus off the job training", International Journal of Scientific and Technology Research, vol. 8, no. 10, pp. 671-674.

13. Pavithra, J. \& Ganesan, M. 2016, "A study on awareness and impact of micro-financial schemes", International Journal of Applied Business and Economic Research, vol. 14, no. 8, pp. 5449-5460.

14. Pavithra, J., Dilli Babu, P. \& Ambuli, T.V. 2014, "A study on budgetary control at Maruti Service Masters, Chennai", International Journal of Applied Business and Economic Research, vol. 12, no. 2, pp. 151-161.

15. Gunaraja, T.M. \& Venkatrama Raju, D. 2018, "Determining factors of organisational climate with reference to leadership styles", International Journal of Mechanical Engineering and Technology, vol. 9, no. 9, pp. 1327-1332.

16. Gunaraja, T.M. \& Venkatrama Raju, D. 2018, "The role of job satisfaction and training of employees in determining organisational climate of a selected industry", International Journal of Civil Engineering and Technology, vol. 9, no. 8, pp. 1266-1269.

17. Aarathy, T.S. \& Raju, D.V. 2018, "Performance appraisal and its effects on employees with respect to it sector in Chennai city", International Journal of Civil Engineering and Technology, vol. 9, no. 6, pp. $1535-1538$

18. Aarathy, T.S. \& Raju, D.V. 2018, "Employee perception towards performance appraisal system in IT sector", International Journal of Mechanical Engineering and Technology, vol. 9, no. 5, pp. 131-135.

19. Porselvi, W., Jublee, D. \& Sivanesan, G. 2018, "A study on factor influencing adoption of technology and innovation in banking industry, tamilnadu, India", International Journal of Mechanical Engineering and Technology, vol. 9, no. 5, pp. 789-800.

20. Akessa, G.M. and Dhufera, A.G., 2015. Factors That Influences Students Academic Performance: A Case of Rift Valley University, Jimma, Ethiopia. Journal of Education and Practice, 6(22), pp.55-63.

21. Miller, G. and Shih, C.C., 1999. A faculty assessment of the academic rigor of on-and off-campus courses in agriculture. Journal of Agricultural Education, 40, pp.57-65.

22. Tsinidou, M., Gerogiannis, V. and Fitsilis, P., 2010. Evaluation of the factors that determine quality in higher education: an empirical study. Quality Assurance in education, 18(3), pp.227-244.

23. Farooq, M.S., Chaudhry, A.H., Shafiq, M. and Berhanu, G., 2011. Factors affecting students' quality of academic performance: a case of secondary school level. Journal of quality and technology management, 7(2), pp.1-14.

24. Fitsilis, P., Gerogiannis, V. and Anthopoulos, L., 2014. Ontologies for software project management: a review. Journal of Software Engineering and Applications, 7(13), p.1096.

25. Adams, J.D. and Jaffe, A.B., 1996. Bounding the effects of R\&D: an investigation using matched establishment-firm data(No. w5544) National bureau of economic research. 


\section{AUTHORS PROFILE}

Anudevi Assistant Professor, Department of Science and Humanities, Bharath Institute of Higher Education and Research, Chennai, India.

V.Sailaja Assistant Professor, Department of Science and Humanities, Bharath Institute of Higher Education and Research, Chennai, India.

S.Binapani Assistant Professor, Department of Science and Humanities, Bharath Institute of Higher Education and Research, Chennai, India. 